\title{
Kommentti: Äidinkielen ja kirjallisuuden opettajan arkirealismia lukiossa
}

Tyypillisellä lukion kolmoskurssin lyriikkatunnilla Södergranin tai Saarikosken runon äärellä pyöritellään analyysikeskustelussa yli kymmentä käsitettä: säe, säkeistö, säkeenylitys, puhuja, metafora, metonymia, personifikaatio ja niin edelleen. Nämä käsitteet monien muiden Avain-lehden lukijoille tuttujen käsitteiden rinnalla tekevät analyysista ja tulkinnasta syvemmän kuin keskustelu tai kirjoittaminen käsitteittä. Kaunokirjallisuuden analyysiin harjaantuneen on helppo kuvitella, mitä kaikkea häneltä jää huomioimatta, kun analysoitavana onkin elokuvan Jäniksen vuosi alkukohtaus tai Instrumentariumin viimeisin televisiomainos.

Kun uudessa digitaalisessa äidinkielenkokeessa luku- ja kirjoitustaidon kokeessa teksti voi olla multimodaalinen, hybridi teksti, on selvää, että analyyttinen tarkkuus ei tule olemaan samaa luokkaa, kuin tänä keväänä viimeisen kerran kirjoitettavassa tekstitaidon kokeessa saattoi parhailta kokelailta odottaa.

2000-luvulla Suomessa on harjoitettu genrelähtöistä opetusta. Se ei ehkä olekaan enää tulevaisuudessa keskeistä valmistautumisessa uuteen ylioppilaskokeeseen. Jos kokeessa testattavia tekstilajeja ei rajata, opiskelijoille ei kannata opettaa mitään kovin spesifiä vaan todella yleisluontoisia tietoja ja taitoja. Kun opiskelijoiden kirjoitustaidot heikkenevät, spesifin tekstilajikohtaisen analyysin muotoilu muuttuu entistä haasteellisemmaksi. Outi Oja tuo esille, että lukutaitoon kiinnitetään huomiota, koska juuri sitä on tutkittu. Opettajan arkikokemus tukee ajatusta ennen kaikkea kirjoitustaitojen heikkenemisestä.

Genrelähtöinen opetus ei ehkä ole perusteltu elämänkään kannalta. Tekstilajit tuntuvat muuttuvan koko ajan. Jo ala- ja yläkoulussa harjoitellun uutisen analyysiin eivät oppikirjojen analyysiohjeet enää välttämättä päde. Yksilölliset erot tekstimaailman tuntemuksessa ovat niin ikään suuria, koska valinnanvaraa on paljon. Keskeiseksi tuntuukin nousevan kyky hahmottaa tekstien kontekstien merkityksiä, taito tunnistaa tunteeseen ja järkeen vetoavia argumentteja sekä kertomuksellisuuden ja yksilön kokemuksen merkitystä. Uudessa kokeessa ongelmallista onkin se, että aineistojen konteksti jää usein epäselväksi. Tosielämässä meillä on mahdollisuus hankkia tietoa kontekstista.

Opetan kahta tutkintoa: kansainvälisellä IB-linjalla A-kieltä, jossa luetaan lähinnä kaunokirjallisuutta, sekä kansallisella puolella kieli ja kirjallisuus -oppi- 
ainetta, jonka kuuden pakollisen kurssin aikana pyritään ottamaan haltuun melkoinen määrä erilaisia tekstilajeja julkaisuympäristöineen. Vaikka IBopetus ei ole rinnastettavissa kansallisen opetukseen jo oppituntien suuremman määrän vuoksi, se on kuitenkin osoittanut, että lukutaito ja kirjoitustaito kehittyvät monipuolisiksi, vaikka opiskeltavat tekstit olisivat pelkästään runoa, draamaa ja proosaa. IB-koe on rajattu ja kokeen tekstilajit ovat tiedossa. Sen rinnalla sekä nykyinen että tuleva kansallinen äidinkielen koe vaikuttavat hiukan epäselviltä ja turhan laveilta.

Koska äidinkielen arvosana näyttää yliopistojen uudessa valintakoeprosessissa keskeiseltä, uusi koe tulee ohjaamaan opetusta entistä enemmän. Uusien luku- ja kirjoitustaitojen, muuttuvan kokeen ja erilaisten koulutuspoliittisten visioiden keskellä etsimme tapoja ohjata vastedeskin opiskelijaa luku- ja kirjoitustaitoiseksi toimijaksi, joka on osallinen ja tuntee voivansa vaikuttaa.

Satu Kiiskinen 